\title{
Pembuatan Alat Pemotong, Pencampur dan Pengaduk Pakan Ternak Sapi dengan Metode Logika Fuzzy untuk Meningkatkan Efisiensi Pakan Ternak
}

\section{The Fabrication of Chopping, Mixing and Stiring Cattle Fodder with Fuzzy Method in order toImprove fodder efieciency}

\author{
Budhi Bakhtiar, Roza Susanti \& Hedrick
}

Jurusan Teknik Elektro, Politeknik Negeri Padang

Telp. 0751-72590 Fax. 0751-72576

\section{ABSTRACT}

The growth of cattle majorly affected by the type of fodder and its digestion system. To gain the healthy growth, cattle fed green grass and additional concentrate in form of mixed agricultural wastes such as rice straw, corn straw, etc and tofu residues in cattle fodder. Since cattle have no upper incisor, (insisivus), it use combination of its molar and its tongue to cut the grass or rice straw or corn straw, as the result more fodder like fresh grass, rice straws or corn scraws are wasted. If the wasted re-use by giving it back to cattle, it will not eat it, so it will cause inefficiency in feeding livestock. In order to solve that problem a chopping and mixing tool is needed, by using fuzzy method to control a dc motor constant speed to chopping grass, rice straws and corn straws, and then mixing with additional concentrate such as tofu wasted.

Rice straws, corn straws and fresh grass are chopped in chopping section and mixed with tofu residues in the mixing section. When all the food material mixed and stired, the weight will be measures using a current sensor ACS712-20A. This sensor is used to measure the motor load. Furtheremore, if the more food materials place into this device, so, the faster the dc motor will rotate. When this device loaded 3000gr, the current measure is 4.53 ampere. The load position is not smooth will result the reading of the sensor always fluctuated. As the result, the fuzzy method applied will be optimal when the current is 4.22 ampere and the PWM fuzzy is higher than 252-mark is legible

Keywords: cattle fodder, current sensor ACS712-20A, fuzzy Logic, dc motor

\section{PENDAHULUAN}

Pertumbuhan ternak sapi, erat kaitannya dengan proses pemberian pakan sapi dan jenis jenis pakan yang diberikan. Penurunan populasi ternak sapi potong diduga disebabkan oleh semakin sempitnya lahan, yang dikonversi menjadi lokasi pemukiman, industri atau lahan perkebunan. Penyebab lain adalah semakin kecilnya pemilikan lahan produksi tanaman pangan, sehingga tidak memungkinkan peternak untuk memelihara ternak karena ketersediaan rumput dan limbah hasil pertanian tidak bisa mencukupi kebutuhan pakan. Dalam upaya penyediaan pakan ternak, selain kebutuhan bahan baku yang harus diperhitungkan, maka hal lain yang perlu dipertimbangkan adalah adanya dukungan teknologi dan alat mesin pengolahan pakan agar peternak dapat mengelola pakan dan mendapatkan hasil yang cukup dan baik mutunya. Oleh karena itu, Direktorat Jenderal Peternakan dan Kesehatan Hewan pada tahun 2011 ini memfasilitasi kegiatan pengembangan dan penguatan alat dan mesin pengolah pakan dengan sasaran kelompok yang berada di lokasi integrasi sapi potong. Program pengembangan pakan ternak diarahkan pada pencapaian kemandirian suplai bahan pakan dan pakan serta peningkatan mutu pakan yang akan dilakukan melalui berbagai kegiatan, salah satunya adalah dengan aplikasi kegiatan integrasi ternak sapi potong yang diperkuat dengan penambahan alat mesin pengolah pakan (Ir. Mursyid Ma'sum, M.Agr.)

\section{Penelitian Tentang Upaya Peningakatan Hasil Perternak Sapi.}


Perkembangan di bidang peternakan di Indonesia sudah sangat pesat. Beberapa jenis hewan ternak sudah dibudidayakan secara baik dan optimal. Permasalahan yang timbul adalah proses pengadukan pakan ternak menggunakan cara manual (Charisatul Id Arrizqi). Semakin meningkatnya kesadaran masyarakat untuk mengkonsumsi produk ternak menyebabkan permintaan daging, telur dan susu jugameningkat, namun belum diimbangi dengan suplai dalam negeri yang cukup, sehingga untuk memenuhi kebutuhan masyarakat tersebut kita terpaksa harus melakukan importasi, yang tentu saja semakin menguras devisa negara. Kebutuhan akan daging ayam dan telur telah dapat dipenuhi dari produksi dalam negeri, baik dari ayam ras maupun unggas lokal (ayam lokal danitik), namun untuk pemenuhan kebutuhan akan daging sapi sebagian masih harus didatangkan dari negara lain, terutama Australia, New Zealand, Amerika dan Kanada (Ir. Mursyid Ma'sum, M.Agr)

\section{Mesin pencacah rumput}

Mesin ini merupakan mesin serbagun untuk perajang hijauan,nkhususnya digunakan untuk merajang rumput pakan ternak. Pencacahan ini dimaksudkan untuk mempermudah ternak dalam memakan, disamping itu juga untuk memperirit rumput.Mesin pencacah rumput pakan ternak hasil modifikasi ini menggunakan motor listrik sebagai sumber tenaga penggerak. Mesin ini mempunyai sistem transmisi tunggal yang berupa sepasang pulley dengan perantara v-belt. Saat motor listrik dinyalakan, maka putaran motor listrik akan langsung ditransmisikan ke pulley 1 yang dipasang seporos dengan motor listrik. Dari pulley 1, putaran akan ditransmisikan ke pulley 2 melalui perantara v-belt, kemudian pulley 2 berputar, maka poros yangberhubungan dengan pulley akan berputar sekaligus memutar pisau perajang. Hal tersebut dikarenakan pisau perajang dipasang seporos dengan pulley 2. Meski terkesan memiliki fungsi yang sederhana namun mesin berperan cukup besar dalam proses pencacahan. Mesin pencacah rumput ini terdapat beberapa bagian utama seperti; motor penggerak, poros, casing, sistem transmisi dan pisau perajang (Muhamad Arfiyanto)

\section{Kontrol Fuzzy}

Fuzzy Logic Controller merupakan alternatif sistem kendali modern yang mudah karena tidak perlu dicari model matematis dari suatu sistem, tetapi tetap efektif karena memiliki respon sistem yang stabil. Alat pembuat gerabah yang direncanakan diputar oleh motor DC Servo yang dikontrol oleh mikrokontroler dan metode pengaturan yang digunakan adalah fuzzy logic. Fuzzy logic yang dirancang memiliki 2 input (Err \& DErr) dan 1 output (Doutput). Masing-masing membership function memiliki 5 label. Disini digunakan 25 fuzzy if-then rule yang terdiri atas 9 rule pokok/utama, 10 rule tambahan dan 6 rule pelengkap. Sedangkan proses fuzzy logic terdiri dari fuzzifikasi, evaluasi rule dan yang terakhir defuzzifikasi. Penggerak motor (driver motor) menggunakan sistem PWM (Pulse Width Modulation). Input Setting Point dibatasi antara 0 sampai dengan 255 RPM sesuai dengan yang dibutuhkan [Resmana, 1999].

Pemanfaatan PWM di dalam rangkaian sistem kontrol mikrokontroler yaitu untuk mengatur kecepatan putaran motor, sehingga motor akan berputar sesuai dengan besaran nilai PWM yang telah diberikan. Nilai PWM yang dibangkitkan dari mikrokontroler ini yaitu dengan cara melakukan perhitungan dari metode logika fuzzy. Pengujian PWM ini menggunakan oscilloscope untuk mengetahui bentuk gelombangnya. PWM ini dapat dibangkitkan dari pin khusus timer/counter1 port D4 dan D5 mikrokontroler. Sehingga dapat diatur mode dan cara kerja PWM sedemikian rupa.

Rumput harus disediakan peternak sebagai pakan utama ternak setiap harinya. 
Pakan tambahan juga harus diberikan untuk menambah gizi agar daging ternak lebih cepat berkembang. Pakan tambahan tersebut seperti bekatul, ramuan, sentrat, ketela, ampas tahu dan lainya. Peternak berinisiatif mencampurkan rumput dengan pakan tambahan untuk menghemat biaya. Sebelum dicampur rumput harus dirajang (dicacah) terlebih dahulu, agar dalam proses pencampuran mudah dilakukan. Rumput yang sudah dirajang kemudian dicampur dengan bekatul, potongan ketela, sentrat, sedikit ramuan,garam dan diberi air secukupnya sesuai takaran.

Adapun campuran dari pakan yang diberikan kepada ternak sapi terdiri dari hijauan dan konsentrat. Hijauan merupakan pakan pokok untuk ternak sapi. Terdiri dari beberapa sumber hijauan dan limbah pertanian seperti jerami padi dan rumput serta ampas tahu. Dalam proses pengadukan hijauan ini, sengaja ditambahkan sedikit air dengan kadar air kira kira $14 \%$ sesuai dengan standar SNI 3148.2:2009 dari total pakan yang diaduk. Penambahan air ini bertujuan untuk meningkatkan kadar air di hijauan karena hijauan seperti jerami terlalu kering untuk dimakan ternak.

Susunan gigi sapi mempengaruhi untuk nutrisi sapi, dimana sapi tidak memiliki gigi seri atas, tapi hanya di bagian rahang bawah saja. Di rahang atasnya itu, sapi tida mempunyai gigi seri, tetapi hanya gigi geraham yang jumlahnya lebih banyak dibandingkan manusia. Karena itu, sapi tidak bisa menggigit hanya bisa mengunyah sesuai fungsinya untuk mengunyah makanan berserat (denimulyanasasmita).

Disebabkan sapi tidak mempunyai gigi seri atas ( insisitus) maka proses pencacahan bahan pakan dirasa perlu sebelum memberikan pakan ke ternak. Selain itu, serat dari limbah pertanian seperti jerami, batang jagung yang cukup kasar, dirasa perlu untuk ditambahkan air agar mudah dimakan oleh ternak. Pada proses pengadukan pakan sapi, tingkat kerataan dan kadar air dari bahan pakan penting untuk diperhatikan.
Perancangan merupakan sebuah kegiatan awal dari sebuah usaha dalam merealisasikan sebuah produk yang keberadaannya diperlukan oleh masyarakat untuk meningkatkan kesejahteraan hidupnya (Darmawan,). Sedangkan perancangan mesin berarti perancanaan dari sistem dan segala yang berkaitan dengan sifat mesin-mesin, produk, struktur, alatalat, dan instrument (Joseph and Larry, 1986).

Pada perancangan alat ini akan dibuat lebih ringan agar mudah diangkat, sederhana penggunaannya agar mudah dioperasikan oleh peternak dan dapat diatur kecepatannya dengan menggunakan metode fuzzy sesuai kebutuhan dan juga menggunakan pengaturan kadar air. Penelitian ini mencoba mengembangkan salah satu peralatan pencacah dan pengaduk pakan ternak sapi otomatis untuk peningkatan hasil daging bagi peternak sehingga meringankan kerja peternak mendapatkan hasil sapi yang lebih banyak.

Tujuan dari Penelitian ini adalah Mempermudah pekerjaan peternak dalam pemeliharaan sapi, meningkatkan kwalitas pakan ternak sapi, membuat Alat Pemotong dan pengaduk Pakan Ternak Sapi Otomatis dengan Pengaturan Tingkat Kadar Air yang Praktis, Sederhana, dan lebih ekonomis, menggunakan logika Fuzzy sebagai kontrol dalam pengaturan Pemotong dan Pengadukan pakan ternak sapi.

\section{Ransum Dan Bahan Pakan Ternak Sapi}

Ransum adalah jumlah total bahan makanan yang diberikan pada ternak selama 24 jam. Sedangkan yang dimaksud dengan bahan pakan adalah komponen ransum yang dapat memberikan mamfaat bagi ternak yang mengkonsumsinya. Ransum merupakan factor sangat penting di dalam suatu usaha peternakan, karena ransum berpengaruh langsung terhadap produksi ternak. Perubahan ransum baik secara kualitas maupun kuantitas maupun perubahan pada komponennya akan dapat 
menyebabkan penurunan produksi yang cukup serius.

\section{Jerami Jagung}

Dalam pertanian, brangkasan/jerami adalah sisa-sisa bagian tanaman pertanian (daun, batang, akar) yang tidak dipanen. Dalam beberapa kasus seperti ketika melakukan penelitian, brangkasan juga memiliki arti seluruh bagian tanaman, termasuk komponen yang dipanen. Pemanfaatan hasil ikutan tanaman jagung berupa batang dan daun yang masih muda, dikenal sebagai jerami jagung dimanfaatkan sebagai hijauan pakan ternak sudah banyak dilakukan petani, namun belum seluruhnya optimal pemanfaatannya. Selain diberikan pada ternak sebagai hijauan segar, jerami jagung juga dapat diberikan sebagai hijauan pakan ternak yang mengalami proses pengolahan teknologi pakan dalam bentuk hay dan silase.

Brangkasan merupakan limbah pertanian yang sangat potensial sebagai pakan ternak karena jumlahnya yang melimpah karena hasil pertanian yang melimpah pula. Setiap hektar tanaman jagung mampu menghasilkan brangkasan (tidak termasuk biji) sebanyak $4200 \mathrm{~kg}$. Brangkasan jagung secara umum memiliki kandungan serat kasar $27,8 \%$ dan protein

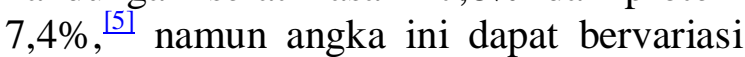
tergantung varietas dan perlakuan saat penanaman. Brangkasan jagung, dibandingkan jerami padi, memiliki kandungan protein lebih tinggi.

\section{Ampas Tahu}

Tahu adalah makanan yang banyak mengandung banyak protein nabati. Hasil sampingan lain dari produksi tahu adalah ampas tahu yang belum banyak dimanfaatkan dan dianggap kurang mempunyai nilai ekonomis. Mengkaji lebih lanjut ampas tahu masih bisa dimanfaatkan sebagai pakan ternak yang banyak kandungan proteinnya.

Ampas tahu adalah salah satu bahan yang dapat digunakan sebagai bahan penyusun ransum. Sampai saat ini ampas tahu cukup mudah didapat dengan harga murah. Ditinjau dari komposisi kimianya ampas tahu dapat dimanfaatkan sebagai sumber protein karena kandungan protein dan lemak pada ampas tahu yang cukup tinggi. Tetapi kandungan tersebut berbeda tergantung tempat dan cara pemprosesannya. Kandungan ampas tahu yaitu protein $8,66 \%$, lemak $3,79 \%$, air $51,63 \%$ dan abu $1,21 \%$, maka sangat memungkinkan ampas tahu untuk diolah menjadi bahan makanan ternak (Dinas Peternakan Propinsi Jawa Timur, 2011).

Rangkaian Sistem Minimum Mikrokontroler Mikrokontroler adalah rangkaian elektronika yang terdiri dari komponenkomponen dasar yang dibutuhkan oleh suatu mikrokontroler untuk dapat berfungsi dengan baik. Pada umumnya, suatu mikrokontoler membutuhkan dua elemen (selain power supply) untuk berfungsi: Kristal Oscillator (XTAL), dan Rangkaian RESET.

Analogi fungsi Kristal Oscillator adalah jantung pada tubuh manusia. Perbedaannya, jantung memompa darah dan seluruh kandungannya, sedangkan XTAL memompa data. Dan fungsi rangkaian RESET adalah untuk membuat mikrokontroler memulai kembali pembacaan program, hal tersebut dibutuhkan pada saat mikrokontroler mengalami gangguan dalam meng-eksekusi program.

\section{Sensor Kelembaban DHT-11}

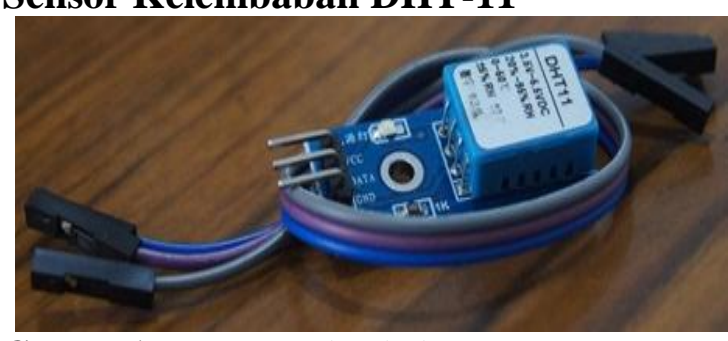

Gamar 1. Sensor Kelembaban DHT-11

DHT11 adalah sensor Suhu dan Kelembaban, dia memiliki keluaran sinyal digital yang dikalibrasi dengan sensor suhu dan kelembaban yang kompleks. Teknologi ini memastikan keandalan tinggi dan sangat baik stabilitasnya dalam jangka panjang. mikrokontroler terhubung pada kinerja tinggi sebesar 8 bit. Sensor ini termasuk elemen resistif dan perangkat pengukur 
suhu NTC. Memiliki kualitas yang sangat baik, respon cepat, kemampuan antigangguan dan keuntungan biaya tinggi kinerja.

Setiap sensor DHT11 memiliki fitur kalibrasi sangat akurat dari kelembaban ruang kalibrasi. Koefisien kalibrasi yang disimpan dalam memori program OTP, sensor internal mendeteksi sinyal dalam proses, kita harus menyebutnya koefisien kalibrasi. Sistem antarmuka tunggal-kabel serial terintegrasi untuk menjadi cepat dan mudah. Kecil ukuran, daya rendah, sinyal transmisi jarak hingga 20 meter, sehingga berbagai aplikasi dan bahkan aplikasi yang paling menuntut. Produk ini 4-pin pin baris paket tunggal. Koneksi nyaman, paket khusus dapat diberikan sesuai dengan kebutuhan pengguna.

spesifikasi

- Pasokan Voltage: $5 \mathrm{~V}$

- Rentang temperatur :0-50 ${ }^{\circ} \mathrm{C}$ kesalahan \pm $2^{\circ} \mathrm{C}$

- Kelembaban :20-90\% RH $\pm 5 \%$ RH error

- Interface: Digital

\section{METODOLOGI}

\section{Ransum Dan Bahan Pakan Ternak Sapi}

Ransum adalah jumlah total bahan makanan yang diberikan pada ternak selama 24 jam. Sedangkan yang dimaksud dengan bahan pakan adalah komposisi ransum yang dapat memberikan mamfaat bagi ternak yang mengkonsumsinya. Bagi semua makhluk hidup, pakan mempunyai peranan sangat penting sebagai sumber energi untuk pemeliharaan tubuh, pertumbuhan dan perkembangbiakan. Fungsi lainnya diantaranya yaitu sebagai pengobatan, reproduksi, perbaikan metabolisme lemak dan lain-lain.

Berikut ini adalh cara kerja alat pemotong:

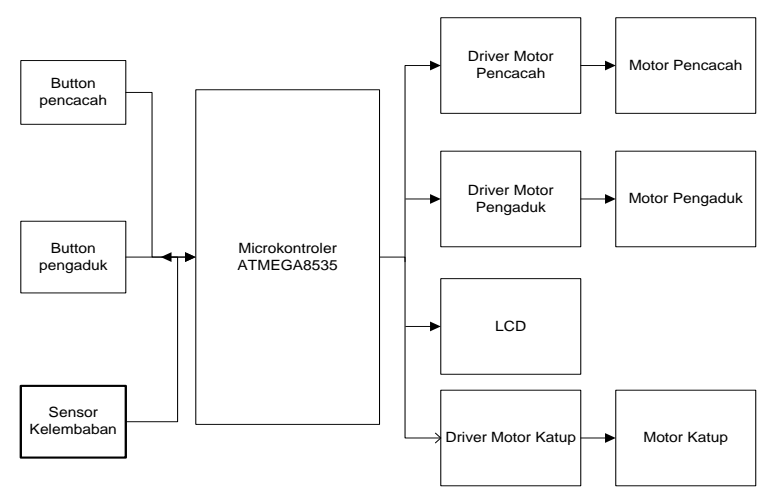

Gambar 2.Sistem Kerja Alat Pemotong Dan Pengaduk Pakan Ternak (Sapi)

Diagram alir dari proses pencacahan dan pengadukan pakan adalah sebagai berikut:

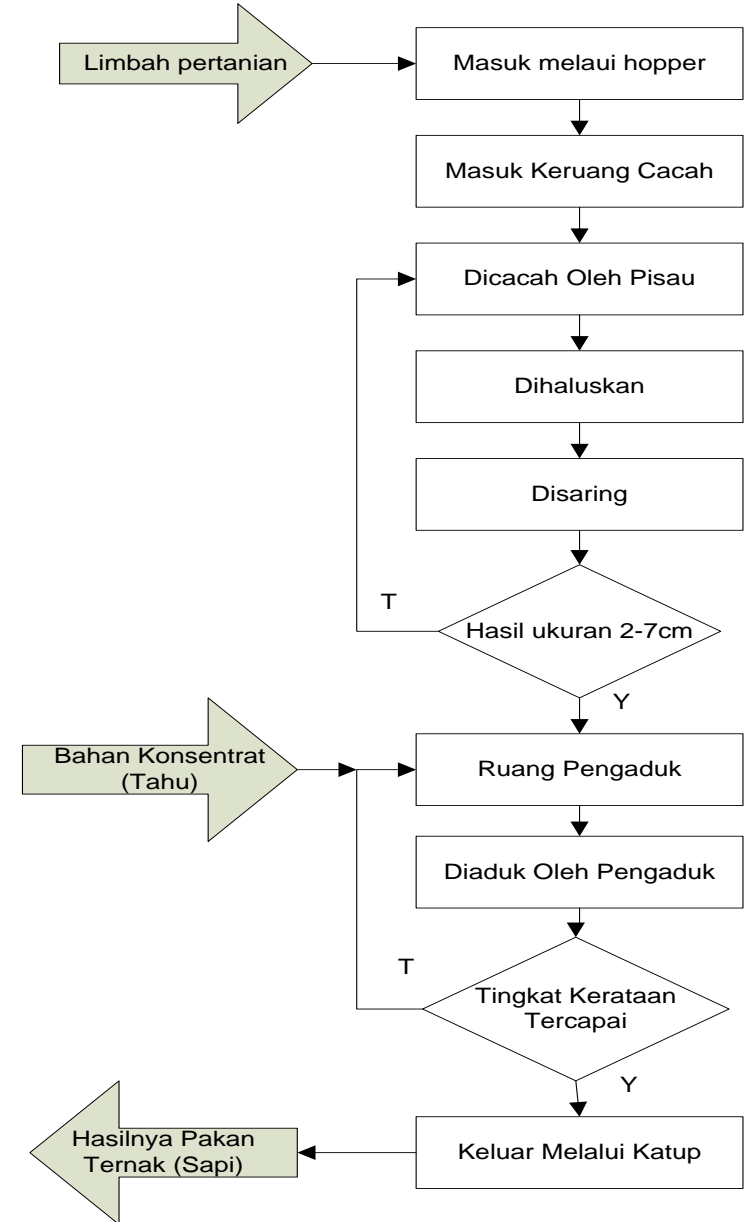

Gambar 3.Diagram alur proses pencacahan dan pengadukan pakan

Pada perancangan sistem fuzzy terdapat beberapa tahapan yang dilalui seperti yang dapat dilihat pada blok diagram berikut ini :

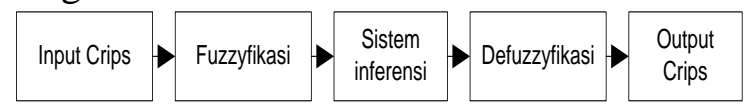

Gambar 4. Tahapan fuzzy 
Fuzzyfikasi adalah tahapan pembuatan Membership function berupa penentuan crips input dan output yang menjadi variabel fuzzy . Adapun variabel yang digunakan pada sistem fuzzy pada alat ini yaitu, crips input berupa error (beban) dan d-error ( $P W M$ motor) sedangkan crips output berupa $\mathrm{Z}$ (nilai untuk pengurangan $P W M$ dan penambahan $P W M$ ). Pada perancangan fuzzy ini, nilai error (beban) diperoleh dari nilai yang terbaca oleh sensor arus, nilai delta error $(P W M)$ diperoleh dari nilai $P W M$ motor. Membership function untuk error yaitu:

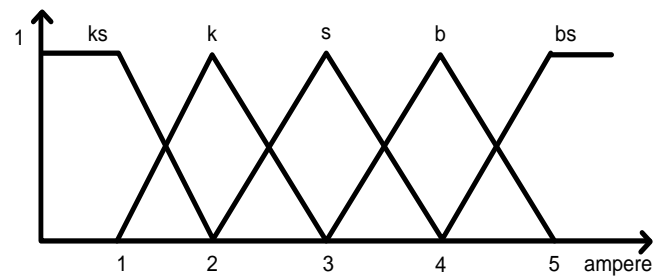

Gambar 5. Fungsi keanggotaan error

Keterangan :
a. Lambat sekali (LS) lambat sekali
$=\mathrm{d}$-error
b. Lambat (L)
lambat
$=\mathrm{d}$-error
c. $\quad \operatorname{Normal}(\mathrm{N})$ normal
d. $\quad$ Cepat $(\mathrm{C})$ cepat
e. Cepat Sekali (CS) cepat sekali

\section{HASIL DAN PEMBAHASAN \\ Kondisi bahan baku}

1) Varitas makanan sapi yang digunakan harus sama

2) Makanan yang digunakan batang jagung dan rumput yang segar

\section{Kondisi mesin}

1) Kecepatan putar mesin diatur pada kondisi optimum dan diketahui kecepatannya.

2) Mesin yang digunakan harus kokoh, kuat dan aman.

3) Pengujian dilakukan seteiah mesin berjaian stabil.

\section{Pelaksanaan Pengujian Kapasitas produksi mesin}

Mesin mampu menghasilkan proses pencacahan $\pm 12,5 \mathrm{~kg}$ dalam 1 menit. perhitungan kapasitas mesin secara sistematis :

1 menit $=12,5 \mathrm{~kg}$

$1 \mathrm{jam}=12,5 \mathrm{~kg} \mathrm{x} 60$ $=750 \mathrm{~kg} / \mathrm{jam}$

Perhitungan biaya operasional menggunakan mesin dengan tenaga manusia :

Motor listrik yang digunakan $1 \mathrm{HP}$ dengan kapasitas listrik terpasang 900 VoltAmpere. $1 \mathrm{HP}=746$ watt $746 \mathrm{wh}=746 / 1000 \mathrm{Kwh}=0,746 \mathrm{Kwh}$

Tarif harga listrik berdasarkan PLN untuk kategori rumah tangga dengan daya 900 watt berkisar antara Rp. 275 - Rp. 300 per Kwh.

Maka,

$$
\begin{aligned}
\text { Rp/jam listrik }= & (\text { watt/1000) } \times(\text { harga } \\
& \text { listrik/Kwh }) \\
= & (746 / 1000) \times 300 \\
= & \operatorname{Rp} .223,8 / \text { jam } \approx \\
& \operatorname{Rp~250/jam~}
\end{aligned}
$$

Jika upah tenaga Rp 40.000/8jam, maka untuk membayar upah tenaga 1 jam $\mathrm{Rp}$. 5.000. Jadi biaya /jam pemakaian mesin memerlukan biaya Rp 5.250.

Jika menggunakan sabit, dalam 1 jam pencacahan memperoleh hasil cacahan maksimal $100 \mathrm{~kg}$, untuk mendapatkan 750 kg membutuhkan waktu 7 jam 30 menit dengan biaya tenaga pemotongan sekitar Rp. 40.000. Maka jelas terlihat menggunakan mesin dalam proses pencacahan lebih efisien dan lebih murah dibandingkan dengan menggunakan tenaga manusia.

\section{Uji Kadar Air}

Dimana nilai kadar air sesuai dengan standar SNI 3148.2:2009 yaitu dengan standar kepadatan degan nilai $14 \%$

Pengujian Rangkaian Driver Motor $\mathrm{H}$ Bridge

Pengujian rangkaian Driver motor $H$ Bridge dilakukan untuk mengetahui rangkaian Driver motor dapat bekerja dengan baik sesuai dengan logika yang diberikan oleh mikrokontroler ATMega32. 
Rangkaian Driver motor $\mathrm{H}$-Bridge dapat dilihat dari gambar 58 berikut :

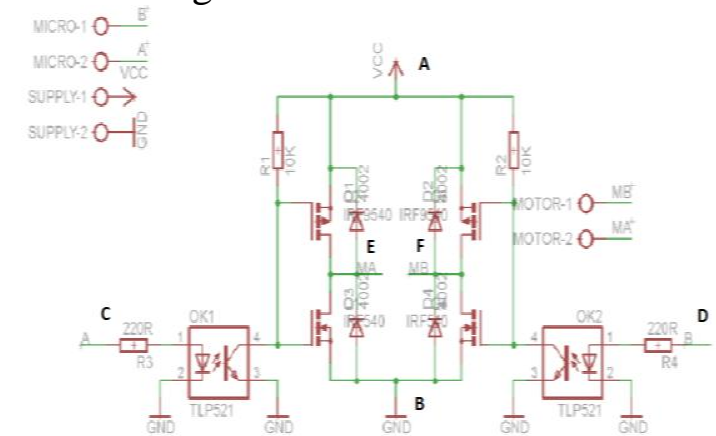

Gambar 6. Rangkaian Driver Motor H-Bridge Adapun beberapa titik pengujian Driver motor $H$-Bridge ini sebagai berikut : Tabel 6. Hasil pengujian rangkaian Driver H-Bridge

\begin{tabular}{|c|c|}
\hline Titik Pengukuran & $\begin{array}{c}\text { Hasil } \\
\text { Pengukuran } \\
\text { Voltmeter (volt) }\end{array}$ \\
\hline A - B & 17.5 V DC \\
\hline C - D & 4.4 V DC \\
\hline $\begin{array}{c}\text { D - C (posisi + probe } \\
\text { ditukar saat pengukuran) }\end{array}$ & -4.4 V DC \\
\hline E - F & 17.5 VDC \\
\hline $\begin{array}{c}\text { F - E (posisi + probe } \\
\text { ditukar saat } \\
\text { pengukuran) }\end{array}$ & -17.5 V DC \\
\hline
\end{tabular}

Pengujian pada rangkaian Driver motor H-Bridge dilakukan dengan memberikan logika 1 atau logika 0 dari mikrokontroler. Proses pengujian tegangan pada rangkaian Driver motor $H$-Bridge dilakukan dengan menggunakan voltmeter pada beberapa titik penggukuran yaitu, input tegangan Driver motor, input dari sistim minimum dan output dari Driver motor.

Logika Fuzzy dapat membantu dalam mengambil keputusan. Berdasarkan tabel hasil pengujian diatas, nilai output dari proses fuzzy akan menghasilkan output fuzzy berupa variabel penambahan nilai $P W M$. Nilai $P W M$ ini akan terus mengalami penambahan hingga tercapai nilai $P W M$ yang sesuai dengan nilai arus yang terbaca oleh sensor arus. Adapun beberapa tahapan yang dilakukan untuk memperoleh output variabel penambahan nilai fuzzy adalah sebagai berikut :

Fuzzyfikasi untuk error (arus) Saat arus $=1.83$ : $(\mathrm{x}>\mathrm{rs} \quad \& \& \quad \mathrm{x}<\mathrm{r}) \quad\{\mathrm{u} 1=(\mathrm{r}-\mathrm{x}) /(\mathrm{r}-\mathrm{rs}) ; \quad \mathrm{u} 2=(\mathrm{x}-$ rs $) /(\mathrm{r}-\mathrm{rs}) ; \mathrm{u} 3=0 ; \mathrm{u} 4=0 ; \mathrm{u} 5=0$;

Fuzzyfikasi untuk delta error (PWM) saat $P W M=120$ :

$(\mathrm{y}>\mathrm{ls} \& \& \mathrm{y}<\mathrm{t}) \quad\{\mathrm{Au} 1=0 ; \mathrm{Au} 2=(\mathrm{t}-\mathrm{y}) /(\mathrm{t}-\mathrm{ls})$; Au3 $=(y-1 s) /(t-l s) ;$ Au4 $=0 ;$ Au $5=0 ;\}$

Untuk membuktikan program proses fuzzyfikasi dapat diuji dengan menggunakan perhitungan untuk arus = 1.83 ampere dan $P W M=120$, maka nilai error dan delta error nya sebagai berikut :

Arus $=1.83$ ampere artinya nilai sensor berada pada range $(\mathrm{y}>\mathrm{ls} \& \& \mathrm{y}<\mathrm{t})$. Maka dapat dicari nilai u1, u2, u3, u4, dan u5 sebagai berikut :

$\mathrm{U} 1=(\mathrm{k}-\mathrm{x}) /(\mathrm{k}-\mathrm{ks})=2-1.83 / 2-1=0.17$

$\mathrm{U} 2=(\mathrm{x}-\mathrm{ks}) /(\mathrm{k}-\mathrm{ks})=1.83-1 / 2-1=0.83$

$\mathrm{U} 3=0 ; \mathrm{u} 4=0 ; \mathrm{u} 5=0$

$P W M=120$ artinya nilai $P W M$ berada pada range $(\mathrm{y}>\mathrm{ls} \& \& \mathrm{y}<\mathrm{t})$. Maka dapat dicari nilai Au1, Au2, Au3, Au4, dan Au5 sebagai berikut :

$\mathrm{Au} 1=0$

$\mathrm{Au} 2=(\mathrm{t}-\mathrm{y}) /(\mathrm{t}-\mathrm{ls})=170-120 / 170-110=$ $50 / 60=0.83$

Au3 $=(\mathrm{y}-\mathrm{ls}) /(\mathrm{t}-\mathrm{ls})=120-110 / 170-110=$ $10 / 60=0.17$

$\mathrm{Au} 4=0 \quad \mathrm{Au} 5=0$

Langkah selanjutnya dalam Logika Fuzzy ini yaitu dengan menentukan rule base dari Logika Fuzzy . Rule base itu sendiri merupakan kelompok aturan logika dalam berhubungan dengan keadaan sinyal masukan dan sinyal keluaran. Proses rule base berfungsi untuk mencari nilai output fuzzy dari input fuzzy yang diberikan. Proses rule base dilakukan untuk mencari nilai terkecil antara hasil dari perhitungan error(arus) dengan delta-error ( $P W M)$ agar memperoleh nilai $a$-predikat sehingga nilai tesebut digunakan untuk mencari nilai ztotal pada proses defuzzyfikasi. Berikut contoh perhitungan dari proses rule base saat Arus $=1.83, \mathrm{U} 1=0.17, \mathrm{U} 2=0.83, \mathrm{U} 3$ $=0, \mathrm{U} 4=0, \mathrm{U} 5=0, P W M=120, \mathrm{Au} 1=0$, $\mathrm{Au} 2=0.83, \mathrm{Au} 3=0.17, \mathrm{Au} 4=0, \mathrm{Au} 5=0$ :

Nilai $z$

1. if (u1<Au1) $\{b 1=u 1$; \}else b1=Au1; $\mathrm{z} 1=(1+(\mathrm{b} 1 *(\mathrm{~m}-\mathrm{l}))) ;=(-20+(0 *(0+20)))=-$ 20 
$\mathrm{z} 2=(\mathrm{n}-(\mathrm{b} 1 *(\mathrm{n}-\mathrm{m}))) ;=(20-(0 *(20-0))) ;=20$

2. if (u2<Au1) $\{b 2=u 2$; $\}$ else b2=Au1; $\mathrm{z} 3=(\mathrm{m}+(\mathrm{b} 2 *(\mathrm{n}-\mathrm{m}))) ;=(0+(0 *(20-0))) ;=0$ $\mathrm{z} 4=(\mathrm{o}-(\mathrm{b} 2 *(\mathrm{o}-\mathrm{n}))) ;=(40-(0 *(40-20))) ;=40$

3. if $(u 3<A u 1)\{b 3=u 3$; $\}$ else $b 3=A u 1$; $\mathrm{z} 5=(\mathrm{n}+(\mathrm{b} 3 *(\mathrm{o}-\mathrm{n}))) ;=(20+(0 *(40-$ 20)) $) ;=20$

4. if $(u 4<A u 1)\{b 4=u 4$; $\}$ else $b 4=A u 1$; $\mathrm{z} 6=(\mathrm{n}+(\mathrm{b} 4 *(\mathrm{o}-\mathrm{n}))) ;=(20+(0 *(40-$ 20)) $) ;=20$

5. if (u5<Au1) $\{$ b5 $=u 5$; $\}$ else b5=Au1; $\mathrm{z} 7=(\mathrm{n}+(\mathrm{b} 5 *(\mathrm{o}-\mathrm{n}))) ;=(20+(0 *(40-$ 20)) $) ;=20$

6. if $(\mathrm{u} 1<\mathrm{Au} 2)\{\mathrm{b} 6=\mathrm{u} 1$; $\}$ else $\mathrm{b} 6=\mathrm{Au} 2$; $\mathrm{z} 8=(\mathrm{k}+(\mathrm{b} 6 *(1-\mathrm{k}))) ;=(-40+(0.17 *(-$ $20+40))) ;=-36.6$ $\mathrm{z} 9=(\mathrm{m}-(\mathrm{b} 6 *(\mathrm{~m}-\mathrm{l}))) ;=(0-(0.17 *(0+20)))$; $=-3.4$

7. if (u2<Au2) $\{b 7=u 2$; \}else b7=Au2; $\mathrm{z} 10=(1+(\mathrm{b} 7 *(\mathrm{~m}-1))) ;=(-$ $20+(0.83 *(0+20)))=-3.4$ $\mathrm{z} 11=(\mathrm{n}-(\mathrm{b} 7 *(\mathrm{n}-\mathrm{m}))) ;=(20-(0.83 *(20-0))) ;$ $=3.4$

8. if (u3<Au2) $\{b 8=u 3$; $\}$ else $b 8=A u 2$; $\mathrm{z} 12=(\mathrm{m}+(\mathrm{b} 8 *(\mathrm{n}-\mathrm{m}))) ;=(0+(0 *(20-0))) ;=0$ $\mathrm{z} 13=(\mathrm{o}-(\mathrm{b} 8 *(\mathrm{o}-\mathrm{n}))) ;=(40-(0 *(40-$ 20)) $) ;=40$

9. if $(u 4<A u 2)\{b 9=u 4$; $\}$ else $b 9=A u 2$; $\mathrm{z} 14=(\mathrm{n}+(\mathrm{b} 9 *(\mathrm{o}-\mathrm{n}))) ;=(20+(0 *(40-$ 20)) $) ;=20$

10. if $(u 5<A u 2)\{b 10=u 5 ;\}$ else b10=Au2; $\mathrm{z} 15=(\mathrm{n}+(\mathrm{b} 10 *(\mathrm{o}-\mathrm{n}))) ;=(20+(0 *(40-$ 20)) $) ;=20$

11. if $(u 1<A u 3)\{b 11=u 1$; $\}$ else b11=Au3; $\mathrm{z} 16=(1-(\mathrm{b} 11 *(\mathrm{l}-\mathrm{k}))) ;=(-20-(0.17 *(-$ $20+40))) ;=-16.6$

12. if $(u 2<A u 3)\{b 12=u 2$; $\}$ else b12=Au3; $\mathrm{z} 17=(\mathrm{k}+(\mathrm{b} 12 *(1-\mathrm{k}))) ;=(-40+(0.17 *(-$ $20+40))) ;=-36.6$ $\mathrm{z} 18=(\mathrm{n}-(\mathrm{b} 12 *(\mathrm{~m}-1))) ;=(20-$ $(0.17 *(0+20))) ;=16.6$

13. if $(u 3<A u 3)\{b 13=u 3$; $\}$ else b13=Au3; $\mathrm{z} 19=(\mathrm{l}+(\mathrm{b} 13 *(\mathrm{~m}-\mathrm{l}))) ;=(-20+(0 *(0+40)))=$ $-20$

$\mathrm{z} 20=(\mathrm{n}-(\mathrm{b} 13 *(\mathrm{n}-\mathrm{m}))) ;=(20-(0 *(20-0))) ;=$ 20

14. if (u4<Au3) $\{$ b14=u4; \}else b14=Au3; $\mathrm{z} 21=(\mathrm{m}+(\mathrm{b} 14 *(\mathrm{n}-\mathrm{m}))) ;=(0+(0 *(20-$ $0))) ;=0$ $\mathrm{z} 22=(\mathrm{o}-(\mathrm{b} 14 *(\mathrm{o}-\mathrm{n}))) ;=(40-(0 *(40-$

$$
\text { 20) ));=40 }
$$

15. if (u5<Au3) $\{b 15=u 5$; $\}$ else b15=Au3; $\mathrm{z} 23=(\mathrm{n}+(\mathrm{b} 15 *(\mathrm{o}-\mathrm{n}))) ;=(20+(0 *(40-$ 20)) $) ;=20$

16. if $(u 1<A u 4)\{b 16=u 1$; \}else b16=Au4; $\mathrm{z} 24=\left(1-\left(\mathrm{b} 16^{*}(\mathrm{l}-\mathrm{k})\right)\right) ;=(-20-(0 *(-$ $20+40))) ;=-20$

17. if (u2<Au4) $\{$ b17 $=u 2$; $\}$ else b17=Au4; $\mathrm{z} 25=(\mathrm{l}-(\mathrm{b} 17 *(\mathrm{l}-\mathrm{k}))) ;=(-20-(0 *(-$

$20+40))) ;=-20$

18. if $(u 3<A u 4)\{b 18=u 3$; $\}$ else b18=Au4; $\mathrm{z} 26=(\mathrm{k}+(\mathrm{b} 18 *(\mathrm{l}-\mathrm{k}))) ;=(-40+(0 *(-$

$20+40))) ;=-40$

$\mathrm{z} 27=(\mathrm{m}-(\mathrm{b} 18 *(\mathrm{~m}-\mathrm{l}))) ;=(0-(0 *(0+20))) ;$ $=0$

19. if $(u 4<A u 4)\{b 19=u 4$; $\}$ else b19=Au4; $\mathrm{z} 28=(\mathrm{l}+(\mathrm{b} 19 *(\mathrm{~m}-\mathrm{l}))) ;=(-20+(0 *(0+40)))=$ $-20$

$\mathrm{z} 29=(\mathrm{n}-(\mathrm{b} 19 *(\mathrm{n}-\mathrm{m}))) ;=(20-(0 *(10-0))) ;=$ 20

20. if $(u 5<A u 4)\{b 20=u 5$; $\}$ else b20 $=A u 4$; $\mathrm{z} 30=(\mathrm{m}+(\mathrm{b} 20 *(\mathrm{n}-\mathrm{m}))) ;=(0+(0 *(20-$

$0))) ;=0$

$\mathrm{z} 31=(\mathrm{o}-(\mathrm{b} 20 *(\mathrm{o}-\mathrm{n}))) ;=(40-(0 *(40-$ 20)) $) ;=40$

21. if $(u 1<A u 5)\{b 21=u 1$; $\}$ else b21=Au5; $\mathrm{z} 32=(1-(\mathrm{b} 21 *(1-\mathrm{k}))) ; \quad=(-20-(0 *(-$ $20+40))) ;=-20$

22. if $(u 2<A u 5)\{b 22=u 2$; $\}$ else b22 $=A u 5$; $\mathrm{z} 33=(1-(\mathrm{b} 22 *(1-\mathrm{k}))) ;=(-20-(0 *(-$ $20+40))) ;=-20$

23. if (u3<Au5) $\{b 23=u 3$; $\}$ else b23=Au5; $\mathrm{z} 34=(1-(\mathrm{b} 23 *(1-\mathrm{k}))) ;=\left(-20-\left(0^{*}(-\right.\right.$ $20+40))) ;=-20$

24. if (u4<Au5) $\{$ b24=u4; $\}$ else b24=Au5; $\mathrm{z} 35=(\mathrm{k}+(\mathrm{b} 24 *(\mathrm{l}-\mathrm{k}))) ;=(-40+(0 *(-$ $20+40))) ;=-40$ $\mathrm{z} 36=(\mathrm{m}-(\mathrm{b} 24 *(\mathrm{~m}-1))) ;=(0-(0 *(0+20))) ;$ $=0$

25. if (u5<Au5) $\{b 25=u 5$; $\}$ else b25 $=A u 5$; $\mathrm{z} 37=\left(1+\left(\mathrm{b} 25^{*}(\mathrm{~m}-1)\right)\right) ;=(-20+(0 *(0+20)))=$ $-20$

$\mathrm{z} 38=(\mathrm{n}-(\mathrm{b} 25 *(\mathrm{n}-\mathrm{m}))) ;=(20-(0 *(20-0))) ;=$ 20

Setelah memperoleh nilai z1-z38 dari proses rule base, maka selanjutnya kita dapat memperoleh nilai $\mathrm{z}$ total melalui proses defuzzyfikasi. Proses defuzzyfikasi merupakan proses untuk mencari nilai rata 
rata $\mathrm{z}$ yang biasa disebut ztotal dengan menggunakan metode tsukamoto

\section{Tahap Penelitian}

Tahapan yang akan dilakukan pada penelitian ini adalah sebagai berikut:

1. Penelitian akan dimulai dengan studi mengenai penangan sistem paska daging sapi serta Referensi dan literature tertentu akan dibutuhkan untuk mendukung kegiatan ini dalam bentuk buku, jurnal dan sebagainya, termasuk sumber dari internet

2. Sebagai persiapan sebelum memulai disain, maka diperlukan pemahaman sistem peralatan pencacah dan pengaduk pakan ternak sapi yang telah dipakai oleh peternak selama ini dan menganalisa kelebihan dan kekurangan sistem yang telah digunakan.

3. Men-simulasikan dan sistem Alat Pemotong Dan Pengaduk Pakan Ternak Sapi Dengan Pengaturan Tingkat Kadar Air dengan program simulasi

4. Membuat sistem pengaturan kecepatan motor DC dengan menggunakan sistem minimum dan menguji kekuatan motor terhadap perubahan beban

5. Membuat Alat Pencacah Dan Pengaduk Pakan Ternak Sapi Dengan Pengaturan Tingkat Kadar Air dengan menggunakan motor DC

6. Menganalisa hasil pakan ternak sapi yang telah dicacah dan diaduk oleh mesin dengan pengaturan tingkat kadar air.

\section{SIMPULAN}

Berdasarkan hasil penelitian, dapat diperoleh beberapa kesimpulan yaitu:

1. Sensor arus ACS712-20A dapat mengukur beban dari putaran motor. Pada saat diberikan beban 3000 gram semakin besar arus yang terukur 4.53
A dan saat diberikan beban yang lebih kecil arus terukur lebih rendah.

2. Posisi beban yang tidak merata selama proses pengadukkan mengakibatkan pengukuran sensor arus selalu berubah

3. Hasil fuzzy bekerja secara optimal terlihat pada tabel 17. Pada saat beban motor maksimal dengan nilai 4,22A maka output pwm fuzzy lebih tinggi dengan nilai 252 .

\section{DAFTAR PUSTAKA}

Andri , Mz . 2014 . Pulse Width Modulation ( Http://Andri_Mz.Staff. Ipb.Ac.Id/ Pulse-Width ModulationPWM, Diakses Pada 3 April 2014 )

Balai Pengkajian Teknologi Pertanian Sumatera Barat. 2010.Sukses Beternak Sapi Dengan Pakan Lokal.Padang: Kementrian Pertanian Badan Penelitian Dan Pengembangan Pertanian

Fitzgerald, A . E . Dkk. ( 1981 ). Dasar Dasar Elektronika Jilid 2. Jakarta : Erlangga 